\title{
OIL CONTENT AND FATTY ACIDS COMPOSITION OF POPPY SEEDS CULTIVATED IN TWO LOCALITIES OF SLOVAKIA
}

\author{
ANDREA LANČARIČOVÁ ${ }^{1 *}$, MICHAELA HAVRLENTOVÁ ${ }^{1,2}$, DARINA MUCHOVÁ ${ }^{1}$ \\ ADRIÁNA BEDNÁROVÁ²
}

\begin{abstract}
${ }^{1}$ National Agricultural and Food Centre - Research Institute of Plant Production, Piešt'any, Slovak Republic ${ }^{2}$ University of Ss. Cyril and Methodius in Trnava, Slovak Republic
\end{abstract}

LANČARIČOVÁ, A. - HAVRLENTOVÁ, M. - MUCHOVÁ, D. - BEDNÁROVÁ, A.: Oil content and fatty acids composition of poppy seeds cultivated in two localities of Slovakia. Agriculture (Pol'nohospodárstvo), vol. 62, 2016, no. 1, p. $19-27$.

Oil content, fatty acids profile, acid and saponification values of poppy seeds grown on two localities of the Slovak Republic were evaluated in the study. Statistically significant effects of locality, genotype and their interaction $(P<0.05)$ for numerous descriptors were proved by non-parametric tests. Results confirmed that variation in the analysed parameters was influenced by the colour of seeds. Ochre variety Redy contained the highest oil level in both localities (49.9 and 52.4\%) and linoleic acid level (74.3 and 71.6\%). White-seeded Racek and Albín had the highest acid value (2.8 and $2.4 \%$ of free fatty acids) and grey-seeded Malsar and blue-seeded Maratón contained the highest saponification value. Buddha, a high-morphine poppy variety, differed significantly in all monitored parameters. High negative interrelation between linoleic and oleic acids levels was observed. Oil content was positively correlated with linoleic acid and negatively with oleic acid. Weather conditions at the end of vegetation influenced the accumulation of oil and essential linoleic acid.

Key words: poppy seed, fatty acid, oil, locality

Poppy (Papaver somniferum L.) is worldwide cultivated as a basic raw material for manufacture of pharmaceutically important narcotics as well as for production of seeds. In 2012, the Czech Republic was a leading producer of poppy seeds in the world with a total production of 12,814 tons (FAOSTAT 2014). On the other hand, the Slovak Republic reached a production of 296 tons. In Slovakia, poppy is cultivated mainly for oily seeds containing $50 \%$ of oil (Luthra \& Singh 1989; Bozan \& Temelli 2008). Seeds are used especially in the food industry as sprinklings and fillings in confectionary and bakery. Because of high content of polyunsaturated fatty acids (PUFAs), they are suitable in human nutrition. Dominant fatty acids in poppies are linoleic and oleic, next palmitic, stearic and alpha-linolenic acids (Nergiz \& Otles 1994; Azcan et al. 2004). Currently, fatty acids attract a great attention thanks to their beneficial effects on human health. Due to high level of PUFAs, poppy seeds and its products are very susceptible to auto-oxidation, resulting in unpleasant odour and bitter taste. Therefore, detailed chemical analysis of oil quality is required for its industrial and nutritive use. Oils of high quality are

RNDr. Andrea Lančaričová, PhD. (*Corresponding author), National Agricultural and Food Centre, Research Institute of Plant Production Piešt’any, Bratislavská 122, Piešt’any, 92168, Slovak Republic. E-mail: lancaricova@vurv.sk

RNDr. Michaela Havrlentová, PhD., National Agricultural and Food Centre, Research Institute of Plant Production Piešt’any, Bratislavská 122, 92168, Piest’any, Slovak Republic. E-mail: havrlentova@vurv.sk

RNDr. Darina Muchová, PhD., National Agricultural and Food Centre, Research Institute of Plant Production Piešt’any Research and Breeding Station at Malý Šariš, Prešov - Malý Šariš, 08001, Slovak Republic, E-mail: muchova@vurv.sk

Mgr. Adriána Bednárová, PhD., Department of Chemistry, Faculty of Natural Sciences, University of Ss. Cyril and Methodius in Trnava, Námestie J. Herdu 2, Trnava, 91701, Slovak Republic. E-mail: bednarova@ucm.sk 
suitable for food industry and cosmetics. Determination of current quality of oil with regard to lipid oxidation can be achieved using procedures as acid value, peroxide value, $\mathrm{p}$-anisidine value. The acid value (free fatty acids) is an important parameter of quality of seed oil and reflects the amount of free fatty acids hydrolysed from triacylglycerols (Berezin et al. 1996). Free fatty acids are a key indicator of hydrolytic degradation associated with off flavour and oil changes (Atinafu \& Bedemo 2011). Saponification value is the average molecular weight of fatty acids, bonded and unbonded acids, present in the oil. Oils with the higher saponification value are suitable for use in cosmetics (Tamzid et al. 2007).

The chemical composition of poppy seeds is influenced by many factors, for example, genotype, environment - locality and year of cultivation. Many studies (Vašák 2010; Azcan et al. 2004; Valizadeh et al. 2014) showed that colour of seed significantly affected some substances of poppy seed (protein, oil and fatty acids). Rahimi et al. (2011) observed high variability in oil and fatty acid amounts of 18 different Turkish poppy varieties. Similarly, Rahimi et al. (2015) evaluated the significant effect of locality on the oil content and fatty acids levels of four poppy genotypes cultivated in two localities of Turkey. According to Hlinková et al. (2012), quality of oil was influenced by environmental conditions of poppy cultivation.

The trend in poppy seed cultivation and exploitation is increasing. Therefore, the aim of the study was to evaluate the basic quality parameters of the seed such as oil content, fatty acids composition, chemical parameters [acid value (AV), free fatty acids (FFAs), respectively, and saponification value $(\mathrm{SV})$ ] in selected poppy varieties cultivated in two localities of Slovakia. The study presents chemometric evaluation of the influence of genotype and locality of cultivation on levels of analysed descriptors. Moreover, the interrelations among studied properties were examined. The colour of poppy seeds in relation to the descriptors was also investigated in this study. For breeders, those results served as valuable information concerning the appropriate conditions of poppy cultivation in Slovakia. Moreover, genotypes with the higher 'added value' could be suitable material for food industry.

\section{MATERIAL AND METHODS}

Field trials were conducted on two localities in Slovakia (Research and Breeding Station at Malý Šariš (east Slovakia) and Vígl'aš-Pstruša (middle Slovakia) in 1 year (2011). Locality Malý Šariš is $21^{\circ} 10^{\prime}$ East longitude, $49^{\circ} 00^{\prime}$ Northern latitude, $310 \mathrm{~m}$ a.s.l., has an annual precipitation $624 \mathrm{~mm}$, an average annual temperature of $8.1^{\circ} \mathrm{C}$. Locality Vígl'aš-Pstruša is $375 \mathrm{~m}$ a.s.1., $19^{\circ} 17^{\prime} 37^{\prime \prime}$ ' East-West longitude, $48^{\circ} 33^{\prime} 19^{\prime \prime}$ 'North-West width, has an annual precipitation $666 \mathrm{~mm}$, an average annual temperature of $8.0^{\circ} \mathrm{C}$. Malý Šariš has a rich content of humus (2.27\%) and Stagni-Haplic Luvisol. The soil was characterised by high content of phosphorus $(158 \mathrm{mg} / \mathrm{kg})$, good content of potassium $(276 \mathrm{mg} / \mathrm{kg})$ and magnesium $(241 \mathrm{mg} / \mathrm{kg})$, with $\mathrm{pH}$ 6.1. The type of soil in Vígl'aš-Pstruša is Stagni-Haplic Luvisol with the lower humus content $(1.6 \%)$ than locality Malý Šariš. The soil was characterised by high content of phosphorus $(138 \mathrm{mg} / \mathrm{kg}$ ), fair content of potassium $(146 \mathrm{mg} / \mathrm{kg})$ and high content of magnesium $(275 \mathrm{mg} / \mathrm{kg})$, with $\mathrm{pH} 5.9$.

$\mathrm{T}$ a

Selected characteristics of evaluated poppy genotypes (country of origin and year of registration)

\begin{tabular}{|l|c|c|}
\hline \multicolumn{1}{|c|}{ Genotype } & $\begin{array}{c}\text { Country of } \\
\text { origin }\end{array}$ & Year of registration \\
\hline Bergam & SK & 1998 \\
Gerlach & SK & 1990 \\
Major & SK & 2002 \\
Malsar & SK & 2002 \\
Maratón & SK & 2000 \\
Opal & SK & 1995 \\
Orfeus & CZ & 2009 \\
Aristo & AT & 2006 \\
Buddha & HU & 2004 \\
Albín & SK & 1991 \\
Racek & CZ & 2008 \\
Redy & CZ & 2008 \\
MS ZB-3 & SK & N \\
MS 387 & SK & N \\
MS 423 & SK & N \\
\hline
\end{tabular}

$\mathrm{N}=$ not registered genotype 
Fifteen poppy genotypes (Papaver somniferum L.) were cultivated in two localities in randomised block design with four replications. Eight varieties (Bergam, Gerlach, Major, Malsar, Maratón, Opal, Albín, Orfeus) were listed at that time in the List of Registered Varieties of the Slovak Republic (ÚKSÚP 2011). Four varieties (Aristo, Buddha, Racek, Redy) are of European origin and three samples are breeding lines (MS ZB-3, MS 387, MS 423). Four colour types, ochre (Redy), white (Albín and Racek), grey (Malsar, restricted variety) and blue were used (Table 1). The seeds were sown on 26 March 2011 (at Vígl'aš-Pstruša) and 29 March 2011 (at Malý Šariš). The date of harvest was 6 August 2011 at Malý Šariš and 16 August 2011 at Vígl'aš-Pstruša. In both localities, plants were treated during the vegetation with herbicides and insecticides on the basis of the current spectrum of weeds and pests. Pre-emergence weed control was provided by systemic herbicide Callisto 480 SC (active substance, mesotrione). As postemergence control was used Laudis OD (active substance, tembotrione) in combination with Starane 250 EC (active substance, fluroxypyr). Against animal pests was applied insecticide Karate Zeon 5 CS (active substance, lambda-cyhalothrin) used as mix with plant stimulator Atonik (3 aromatic nitro compounds). Against gramineous weed species was used Garland Forte (active substance, propaquizafop).

The locality Malý Šariš in 2011 was characterised by the large misalignments of precipitation during the growing season (long-term drought during the germination and in early growth stages of the plant and heavy precipitation at the end of vegetation). Average temperatures for the months from April to July were $0.95^{\circ} \mathrm{C}$ above the long-term average. At Vígl'aš-Pstruša, precipitation and temperature in months April to July were higher than the long-term average. The end of vegetation was characterised by heavy precipitation. Comparison of temperature and precipitation of experimental sites are given in Table 2.

For oil content determination, a method by Soxhlet according to the norm (STN 461011-28) was used in two replications. To evaluate fatty acids composition by gas chromatography (GC), the method of fatty acids methyl esters preparation was used according to Christoperson and Glass (1969). Fatty acids were analysed as their methyl esters by GC (GC-6890 N, Agilent Technologies) using capillary column DB-23 and FID detector under a temperature gradient (Čertík \& Ješko 2006). Fatty acids were identified by authentic standards of C4-C24 fatty acids methyl esters mixture (Supelco, USA) and by ChemStation 10.1 (Agilent Technologies). The degree of fatty acids unsaturation (UI) was calculated in D/mole: UI $=[1(\%$ monoene $)+2(\%$ diene) +3 (\% triene) $] / 100$ (Čertík \& Šajbidor 1996).

AV (calculated as a percentage of FFAs in oil) was determined according to American Oil Chemists' Society (AOCS) Official method: AV (1998). SV of oil was determined using a method ASTM D464 (2010).

Chemometrical data analysis was carried out to discover statistically significant differences among poppy samples according to their genotype and locality of cultivation by means of general linear model (GLM) approach and alternatively by appropriate

T

Meteorological conditions of experimental sites in 2011

\begin{tabular}{|c|c|c|c|c|}
\hline Month & $\begin{array}{c}\text { Temperature } \\
{\left[{ }^{\circ} \mathrm{C}\right]}\end{array}$ & $\begin{array}{c}\text { Precipitation } \\
{[\mathrm{mm}]}\end{array}$ & $\begin{array}{c}\text { Temperature } \\
{\left[{ }^{\circ} \mathrm{C}\right]}\end{array}$ & $\begin{array}{c}\text { Precipitation } \\
{[\mathrm{mm}]}\end{array}$ \\
\hline Locality & \multicolumn{2}{|c|}{ Malý Šariš } & \multicolumn{2}{|c|}{ Vígl'aš-Pstruša } \\
\hline March & 3.5 & 22.1 & 4.3 & 5.1 \\
April & 10.6 & 14.8 & 10.8 & 61.2 \\
May & 14.4 & 56.8 & 13.5 & 85.0 \\
June & 18.3 & 98.7 & 17.5 & 123.2 \\
July & 18.4 & 165.0 & 20.5 & 34.7 \\
August & 19.8 & 18.4 & 17.6 & \\
\hline
\end{tabular}


non-parametric tests. Significant correlations among studied descriptors were done using correlation analysis, specifically non-parametric Spearman correlation analysis. The principal component analysis (PCA) was applied to detect the natural grouping of samples and interrelations between analysed descriptors. Statistical data treatment was performed using SPSS v. 19.0 and STATISTICA v. 10.

\section{RESULTS AND DISCUSSION}

Malý Šariš was characterised by total higher oil values compared to Vígl'aš-Pstruša (Figure 1). However, in both localities, the highest oil content had the ochre variety Redy (49.9\% in Vígl'aš-Pstruša and $52.4 \%$ in Malý Šariš). Moreover, white-seeded varieties were characterised by the higher oil content compared to blue and grey varieties. This result was confirmed in many studies (Azcan et al. 2004; Eklund \& Agreen 1975). Different colours of poppy seed are related to the anatomical structure of the outer layers. White-seeded varieties are characterised by thin seed coat and a high oil content (Vašák 2010). Özcan \& Atalay (2006) showed that oil content in poppy seeds depends on variety and ranged from 32.4 to $45.5 \%$. We assume that oil content is strong genotypic trait. Varieties with white and ochre colour of seed contained the highest oil level, irrespective of locality.
The data in Table 3 show that white seeds contained the highest AV (2.4 and $2.8 \%$ of FFAs) at both localities. Our results are in agreement with the Özcan \& Atalay (2006) and Wagner et al. (2003), which determined $1.6-3.2 \%$ of FFAs in selected varieties. The oxidative and chemical changes during storage of the oil are characterised by an increase in $\mathrm{AV}$, amount of FFAs in the oil, respectively (Perkins 1992). Our results detected the relatively low hydrolytic and lipolytic activities in oil. The maximum limit of $2.0 \%$ of FFAs is reported by Codex Alimentarius (1993).

Varieties registered in the List of Registered Varieties in Slovakia (ÚKSÚP 2011) were characterised by higher SV of oil (Table 3) in range of $174.8 \mathrm{mg}$ $\mathrm{KOH} / \mathrm{g}$ of oil (Major, Malý Šariš) to $204.7 \mathrm{mg}$ $\mathrm{KOH} / \mathrm{g}$ of oil (Malsar, Vígl'aš-Pstruša). No significant differences were found between localities. Our results were different compared to Azcan et al. (2004), which determined higher value, $234 \mathrm{mg}$ $\mathrm{KOH} / \mathrm{g}$ of oil. Our results indicated that selected poppy oils contained the higher levels of low molecular weight fatty acids. We assume that analysed oils have a suitable potential for industrial application, particularly in the manufacture of soaps and cosmetics.

The major fatty acids presented in poppy oil were linoleic (C 18:2), oleic (C 18:1) and palmitic (C 16:0) acids (Table 4). According to the literature, poppy oils contain $50-70 \%$ of linoleic acid,

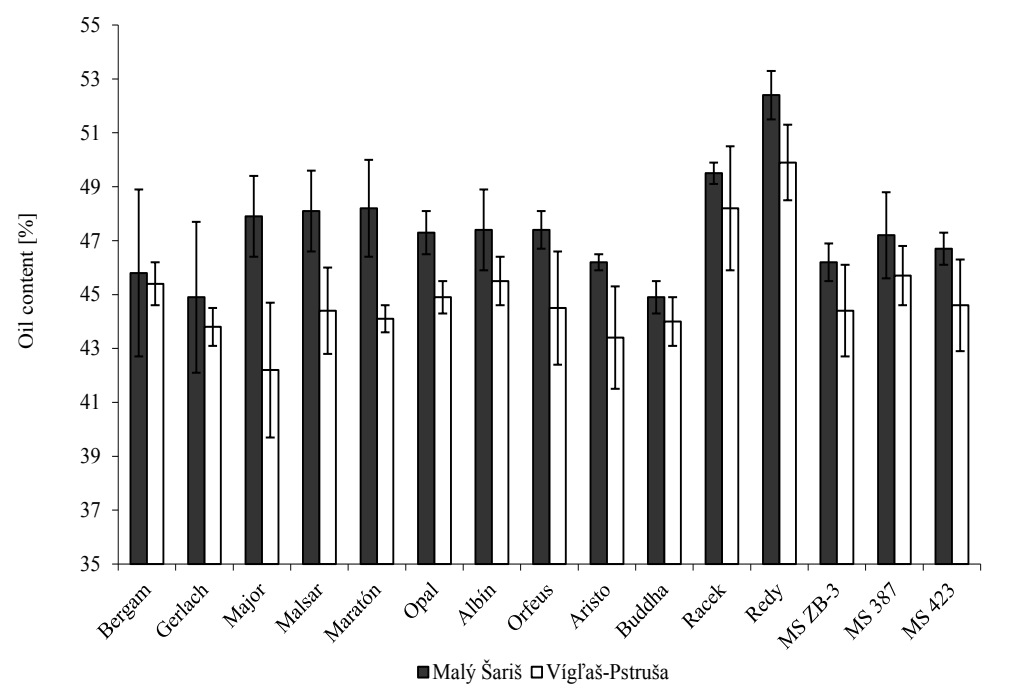

Figure 1. Average oil content [\%] in poppy seeds grown in two localities in one year (Malý Šariš andVígl'ašPstruša) 
$16-30 \%$ of oleic acid and 6-16\% of palmitic acid (Nergiz \& Otles 1994; Azcan et al. 2004). In general, levels of C 18:2 and C 16:0 were higher in Malý Šariš compared to Vígl'aš-Pstruša. For C 18:1 was the situation opposite, higher amounts were detected in Vígl'aš-Pstruša. Variety Buddha (high content of morphine) was characterised by the highest level of $\mathrm{C} 16: 0$ and $C$ 18:1. The highest level of C 18:2 was detected in ochre and in white-seeded poppies. Equally to our results, white-seeded poppies contain higher levels of linoleic acid compared to blue ones (Nergiz \& Otles 1994; Azcan et al. 2004). Absolutely dominant $\mathrm{C} \mathrm{18:2}$ is responsible for the biosynthesis of arachidonic acid and some prostaglandins. Diet enriched with C 18:2 in patients with diabetes caused lower lipoprotein profile (Heine et al. 1989). Stearic (C 18:0) and alpha-linolenic (C 18:3) acids were presented as minor fatty acids (data not shown). Levels of C 18:0 varied from 2\% (Albín) to $2.4 \%$ (Aristo, Racek and Gerlach) in both localities. The highest level of C 18:3 contained Redy in both localities $(0.9 \%)$, however, other genotypes contained very similar levels of C 18:3 (0.7-0.8\%). C 18:3 belongs to the omega-3 fatty acids with positive effect on atherosclerosis, ischemic heart disease, inflammatory diseases and probably also for conduct disorder (Connor 2000). On the other hand, C 18:3 inclines extensively to auto-oxidation; therefore, its high level is an ineligible factor in food industry (Bajpai et al. 1999). Considering this fact, poppy seed is a suitable material to be used in the food industry since it contains relatively low amounts of this fatty acid. Arachidic (C 20:0), gadoleic (C 20:1) and palmitoleic (C 16:1) acids were presented in amounts of $0.1-0.2 \%$. From the levels of fatty acids was detected their high unsaturation in analysed oils. Average values of unsaturation index (UI) were 1.62 (Malý Šariš) and 1.59 (Vígl’aš-

T $\quad \begin{array}{lllllllllllll} & \mathrm{a} & \mathrm{b} & 1 & \mathrm{e} & 3\end{array}$

Chemical properties of poppy seed oils extracted from seeds grown on two localities, Malý Šariš and Vígl'aš-Pstruša

\begin{tabular}{|c|c|c|c|c|c|c|c|c|c|c|}
\hline \multirow{2}{*}{$\begin{array}{l}\text { Descriptor } \\
\text { Locality }\end{array}$} & \multicolumn{2}{|c|}{$\begin{array}{l}\text { SFA } \\
{[\%]}\end{array}$} & \multicolumn{2}{|c|}{$\begin{array}{c}\text { MUFA } \\
{[\%]}\end{array}$} & \multicolumn{2}{|c|}{$\begin{array}{c}\text { PUFA } \\
{[\%]}\end{array}$} & \multicolumn{2}{|c|}{$\begin{array}{l}\text { FFA } \\
{[\%]}\end{array}$} & \multicolumn{2}{|c|}{$\begin{array}{c}\mathrm{SV} \\
{[\mathrm{mg} \mathrm{KOH} / \mathrm{g} \text { of oil] }}\end{array}$} \\
\hline & $\begin{array}{l}\text { Malý } \\
\text { Šariš }\end{array}$ & $\begin{array}{l}\text { Vígl'aš- } \\
\text { Pstruša }\end{array}$ & $\begin{array}{l}\text { Malý } \\
\text { Šariš }\end{array}$ & $\begin{array}{l}\text { Vígl'aš- } \\
\text { Pstruša }\end{array}$ & $\begin{array}{l}\text { Malý } \\
\text { Šariš }\end{array}$ & $\begin{array}{l}\text { Vígl'aš- } \\
\text { Pstruša }\end{array}$ & $\begin{array}{l}\text { Malý } \\
\text { Šariš }\end{array}$ & $\begin{array}{l}\text { Vígl'aš- } \\
\text { Pstruša }\end{array}$ & $\begin{array}{l}\text { Malý } \\
\text { Šariš }\end{array}$ & $\begin{array}{l}\text { Vígl'aš- } \\
\text { Pstruša }\end{array}$ \\
\hline Bergam & $11.0^{+}$ & $10.7^{+}$ & $16.8^{+}$ & $21.0^{+}$ & $72.2^{+}$ & $68.3^{+}$ & 2.2 & 2.3 & 180.1 & 188.4 \\
\hline Gerlach & 11.0 & 10.9 & $15.9^{+}$ & $19.6^{+}$ & $73.1^{+}$ & $69.5^{+}$ & 2.0 & 2.1 & 183.1 & 183.4 \\
\hline Major & 11.2 & 11.1 & $17.4^{+}$ & $19.9^{+}$ & $71.4^{+}$ & $69.0^{+}$ & $2.0^{+}$ & $2.3^{+}$ & 174.8 & 187.5 \\
\hline Malsar & 11.3 & 11.4 & $16.3^{+}$ & $19.5^{+}$ & $72.4^{+}$ & $69.1^{+}$ & $2.2^{+}$ & $1.7^{+}$ & 179.3 & 204.7 \\
\hline Maratón & 11.1 & 11.0 & $16.2^{+}$ & $19.3^{+}$ & $72.7^{+}$ & $69.7^{+}$ & 1.8 & 1.4 & 199.4 & 196.8 \\
\hline Opal & 10.6 & 10.6 & $16.3^{+}$ & $19.3^{+}$ & $73.1^{+}$ & $70.1^{+}$ & $1.7^{+}$ & $1.3^{+}$ & 190.6 & 204.3 \\
\hline Orfeus & 10.8 & 10.8 & $16.3^{+}$ & $19.1^{+}$ & $72.9^{+}$ & $70.0^{+}$ & $1.9^{+}$ & $1.1^{+}$ & $174.8^{+}$ & $198.4^{+}$ \\
\hline Aristo & $12.0^{+}$ & $11.6^{+}$ & $17.1^{+}$ & $19.0^{+}$ & $70.9^{+}$ & $69.4^{+}$ & $2.3^{+}$ & $1.4^{+}$ & $175.6^{+}$ & $198.7^{+}$ \\
\hline Buddha & $12.6^{+}$ & $12.3^{+}$ & $19.7^{+}$ & $23.7^{+}$ & $67.7^{+}$ & $64.0^{+}$ & 2.2 & 1.8 & $173.5^{+}$ & $198.8^{+}$ \\
\hline Albín & $11.2^{+}$ & $11.0^{+}$ & $14.2^{+}$ & $16.8^{+}$ & $74.6^{+}$ & $72.2^{+}$ & 2.4 & 2.2 & $185.7^{+}$ & $193.4^{+}$ \\
\hline Racek & $11.6^{+}$ & $11.4^{+}$ & $13.6^{+}$ & $16.6^{+}$ & $74.8^{+}$ & $72.0^{+}$ & 2.1 & 2.8 & 185.2 & 190.0 \\
\hline Redy & 10.9 & 10.9 & $13.9^{+}$ & $16.6^{+}$ & $75.2^{+}$ & $72.6^{+}$ & $2.1^{+}$ & $2.6^{+}$ & 181.0 & 182.2 \\
\hline MS ZB-3 & $11.5^{+}$ & $11.1^{+}$ & $15.9^{+}$ & $18.9^{+}$ & $72.6^{+}$ & $70.1^{+}$ & $2.0^{+}$ & $2.4^{+}$ & 182.8 & 179.1 \\
\hline MS 387 & 11.3 & 11.3 & $18.5^{+}$ & $20.2^{+}$ & $70.2^{+}$ & $68.5^{+}$ & 1.9 & 2.0 & 176.9 & 178.1 \\
\hline MS 423 & 11.2 & 11.1 & $16.6^{+}$ & $19.3^{+}$ & $72.3^{+}$ & $69.6^{+}$ & 2.1 & 2.0 & 187.0 & 184.9 \\
\hline
\end{tabular}

${ }^{+}$statistically significant differences $(P<0.05)$ between Malý Šariš and Vígl’aš-Pstruša for particular genotypes tested by Mann-Whitney test

SFA - saturated fatty acids; MUFA - monounsaturated fatty acids; PUFA - polyunsaturated fatty acids; FFA free fatty acids; SV - saponification value of oil 
Pstruša). The ratios of oleic acid/linoleic acid (data not shown) were calculated and included to the final statistical evaluation. Our results showed that high morphine variety had the highest amount of saturated fatty acids (SFAs), $12.5 \%$ in average and monounsaturated fatty acids (MUFAs), 21.7\%. Redy disposed by the highest PUFAs in both localities. However, white-seeded varieties Racek and Albín contained a high value of PUFA (difference in tenth of a percent compared to Redy).

According to climatic conditions, there is an assumption that analysed quality parameters could be affected by temperature and precipitation. Malý Šariš was characterised by heavy precipitation at the end of vegetation (June and July) reported in Table 2. However, the average temperature at the end of vegetation was higher in Vígl'aš-Pstruša $\left(19.1^{\circ} \mathrm{C}\right)$. Since the oil content and the level of C 18:2 were higher in Malý Šariš, it could be assumed that lower temperatures and greater precipitation can cause increased accumulation of oil, however, more research needs to be done in this area. Similarly, according Canvin (1965), fatty acid composition was not affected by changes in temperature. However, the amount of higher unsaturated fatty acids decreased with increasing temperature. The fatty acids are important components providing structural barriers against changes in the environment (Beisson et al. 2007). Their levels are influenced by the environmental stress and salinity and heave metals in soil too (Maksymiec 2007; Mikami \& Murata 2003).

The interaction effect genotype $\times$ locality was found to be statistically significant $(P<0.05)$ regarding all analysed descriptors by GLM. Consequently, locality was found statistically significant $(P<0.05)$ for numerous descriptors when considered each genotype category individually (Tables 3 and 4). Besides, the factor genotype was determined as statistically significant $(P<0.05)$ in all investigated descriptors for both levels of locality considered separately. Similarly, Sethi et al. (2006) confirmed the statistically significant effect of genotype and locality on the yield and oil content of poppy seeds.

Statistically significant correlations were found for numerous pairs of descriptors (Table 5). The highest negative correlations were observed between $\mathrm{C}$

T $\quad$ a $\quad$ b 1 e e $\quad 4$

Levels of dominant fatty acids (in \%) in poppy seeds grown in two localities, Malý Šariš and Vígl’aš-Pstruša

\begin{tabular}{|l|c|c|c|c|c|c|}
\hline Descriptor & \multicolumn{2}{|c|}{ C 16:0 } & \multicolumn{2}{c|}{ C 18:1 } & \multicolumn{2}{c|}{ C 18:2 } \\
\hline Locality & Malý Šariš & Vígl'aš-Pstruša & Malý Šariš & Vígl'aš-Pstruša & Malý Šariš & Víglaš-Pstruša \\
\hline Bergam & $8.7 \pm 0.06^{+}$ & $8.3 \pm 0.17^{+}$ & $16.6 \pm 0.67^{+}$ & $20.7 \pm 0.43^{+}$ & $71.4 \pm 0.65^{+}$ & $67.6 \pm 0.33^{+}$ \\
Gerlach & $8.5 \pm 0.01^{+}$ & $8.3 \pm 0.06^{+}$ & $15.6 \pm 0.19^{+}$ & $19.4 \pm 0.17^{+}$ & $72.4 \pm 0.2^{+}$ & $68.7 \pm 0.11^{+}$ \\
Major & $8.8 \pm 0.03^{+}$ & $8.7 \pm 0.06^{+}$ & $17.1 \pm 0.39^{+}$ & $19.6 \pm 0.26^{+}$ & $70.6 \pm 0.42^{+}$ & $68.2 \pm 0.40^{+}$ \\
Malsar & $9.0 \pm 0.05$ & $9.0 \pm 0.06$ & $16.1 \pm 0.14^{+}$ & $19.2 \pm 0.35^{+}$ & $71.6 \pm 0.17^{+}$ & $68.3 \pm 0.27^{+}$ \\
Maratón & $8.7 \pm 0.02^{+}$ & $8.5 \pm 0.09^{+}$ & $15.9 \pm 0.53^{+}$ & $19.1 \pm 0.12^{+}$ & $72.0 \pm 0.58^{+}$ & $68.9 \pm 0.08^{+}$ \\
Opal & $8.2 \pm 0.10$ & $8.1 \pm 0.14$ & $16.1 \pm 0.46^{+}$ & $19.0 \pm 0.31^{+}$ & $72.4 \pm 0.48^{+}$ & $69.3 \pm 0.45^{+}$ \\
Orfeus & $8.4 \pm 0.07$ & $8.4 \pm 0.13$ & $16.1 \pm 0.48^{+}$ & $18.9 \pm 0.2^{+}$ & $72.1 \pm 0.50^{+}$ & $69.3 \pm 0.14^{+}$ \\
Aristo & $9.4 \pm 0.02^{+}$ & $9.0 \pm 0.08^{+}$ & $16.9 \pm 0.17^{+}$ & $18.8 \pm 0.33^{+}$ & $70.2 \pm 0.19^{+}$ & $68.6 \pm 0.35^{+}$ \\
Buddha & $10.1 \pm 0.13^{+}$ & $9.9 \pm 0.12^{+}$ & $19.4 \pm 0.3^{+}$ & $23.4 \pm 0.48^{+}$ & $66.9 \pm 0.38^{+}$ & $63.1 \pm 0.61^{+}$ \\
Albín & $9.1 \pm 0.03^{+}$ & $8.8 \pm 0.32^{+}$ & $13.9 \pm 0.16^{+}$ & $16.5 \pm 0.74^{+}$ & $73.8 \pm 0.14^{+}$ & $71.4 \pm 0.73^{+}$ \\
Racek & $9.1 \pm 0.23^{+}$ & $8.9 \pm 0.22^{+}$ & $13.3 \pm 1.82^{+}$ & $16.3 \pm 0.21^{+}$ & $74.1 \pm 1.61^{+}$ & $71.3 \pm 0.34^{+}$ \\
Redy & $8.6 \pm 0.06$ & $8.5 \pm 0.24$ & $13.6 \pm 0.16^{+}$ & $16.3 \pm 0.38^{+}$ & $74.3 \pm 0.17^{+}$ & $71.6 \pm 0.46^{+}$ \\
MS ZB-3 & $9.1 \pm 0.12^{+}$ & $8.7 \pm 0.11^{+}$ & $15.6 \pm 1.60^{+}$ & $18.6 \pm 0.51^{+}$ & $71.8 \pm 1.47^{+}$ & $69.2 \pm 0.53^{+}$ \\
MS 387 & $9.0 \pm 0.04$ & $8.9 \pm 0.22$ & $18.2 \pm 0.46$ & $19.9 \pm 1.21$ & $69.5 \pm 0.39^{+}$ & $67.7 \pm 0.95^{+}$ \\
MS 423 & $8.8 \pm 0.04^{+}$ & $8.7 \pm 0.04^{+}$ & $16.3 \pm 0.37^{+}$ & $19.0 \pm 0.29^{+}$ & $71.5 \pm 0.44^{+}$ & $68.8 \pm 0.26^{+}$ \\
\hline
\end{tabular}

${ }^{+}$statistically significant differences $(P<0.05)$ between Malý Šariš and Vígl'aš-Pstruša for particular genotypes tested by Mann-Whitney test

C 16:0 - palmitic acid; C 18:1 - oleic acid; C 18:2 - linoleic acid 


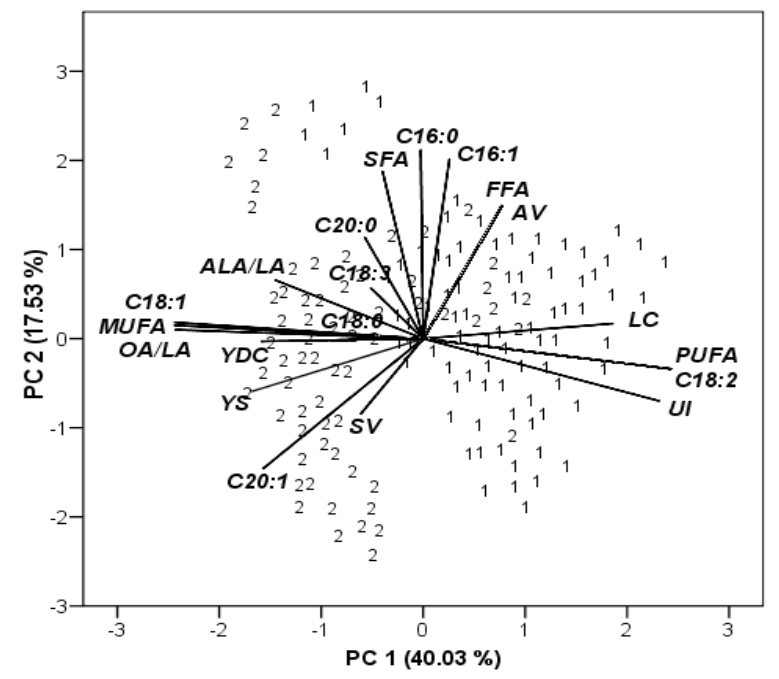

Figure 2. PCA bi-plot showing the mutual position of original variables along with the groups of poppy samples labelled according to locality of cultivation (1 - Malý Šariš, 2 - Vígl’aš-Pstruša). PCA: principal component analysis.

$\mathrm{OA} / \mathrm{LA}$ - oleic/linoleic acid ratio; MUFA - monounsaturated fatty acids; C 18:1 - oleic acid; ALA/LA alpha-linolenic/linoleic acid ratio; YDC - yield of dry capsules; YS - yield of seed; C 20:1 - gadoleic acid; C 18:0 - stearic acid; SV - saponification value; C 20:0 - arachidic acid; C 18:3 - alpha-linolenic acid; SFA - saturated fatty acids; C 16:0 - palmitic acid; C 16:1 - palmitoleic acid; FFA - free fatty acids; AV - acid value; LC - oil content; C 18:2 - linoleic acid; PUFA - polyunsaturated fatty acids; UI - unsaturation index

18:1 and C 18:2 and consequently, between MUFAs and PUFAs. This correlation indicates a competitive relationship between oleic and linoleic acids in the biosynthesis of fatty acids in the poppy seeds. The biosynthesis of fatty acids is a very complex process; all plants produce fatty acids in pathway with precursor acetyl-CoA. PUFAs are synthesised in high plants by both, eukaryotic and prokaryotic pathways (Browse et al. 1986). According to fatty acids profile in our analysed poppies, C 16:0 is elongated to C 18:0 and then stearoyl-CoA-desaturase catalyses conversion of $C$ 18:0 to $C 18: 1$. Desaturases $\left(\Delta^{12}\right.$ and $\Delta^{15}$ ) catalyse a consecutive conversion from oleic acid to linoleic acid and from linoleic to alpha-linolenic acid. C 20:0 and also C 20:1 are formed by the elongation of stearic and oleic acids. Bajpai et al. (1999) confirmed significant positive correlation between yield and oil content and Luthra and Singh (1989) found positive correlations between C 18:0 and C 18:1 and between C 18:2 and C 18:3. Small discordances with our results are presumably occasioned by different poppy material selection and as a consequence, the differences in biosynthesis pattern of fatty acids may occur with respect to the particular genotype and environment.

PCA showed that natural grouping of samples in relation to their locality of cultivation was obvious (Figure 2). Consequently, we concluded, that the quality of poppy seeds depends on their genotype and especially on the locality of growing, that is,

T a b 1 e 5

Reduced correlation (Spearman correlation coefficients $(P<0.05))$ table for all poppy samples $(n=180)$

\begin{tabular}{|l|c|c|c|c|c|c|c|c|c|c|c|}
\hline Descriptor & LC & C 16:0 & C 18:0 & C 18:1 & C 18:2 & C 18:3 & C 20:1 & SFA & MUFA & PUFA & YDC \\
\hline C 18:0 & -0.26 & 0.08 & & & & & & & & & \\
C 18:1 & $-0.67^{+}$ & -0.06 & 0.29 & & & & & & & \\
C 18:2 & $0.67^{+}$ & -0.10 & -0.34 & $-0.97^{+}$ & & & & & & \\
C 18:3 & -0.30 & -0.08 & -0.15 & 0.24 & -0.23 & & & & & \\
C 20:1 & $-0.51^{+}$ & $-0.50^{+}$ & 0.30 & $0.59^{+}$ & $-0.52^{+}$ & 0.14 & & & & & \\
SFA & -0.05 & $0.94^{+}$ & 0.36 & 0.04 & -0.21 & -0.11 & -0.38 & & & \\
MUFA & $-0.67^{+}$ & -0.06 & 0.29 & $1.00^{+}$ & $-0.98^{+}$ & 0.24 & $0.59^{+}$ & 0.04 & & & \\
PUFA & $0.66^{+}$ & -0.11 & -0.35 & $-0.97^{+}$ & $1.00^{+}$ & -0.21 & $-0.52^{+}$ & -0.22 & $-0.97^{+}$ & & \\
YDC & -0.44 & 0.00 & 0.20 & $0.50^{+}$ & $-0.52^{+}$ & 0.48 & 0.49 & 0.08 & $0.50^{+}$ & $-0.51^{+}$ & \\
YS & -0.46 & -0.26 & 0.21 & $0.56^{+}$ & $-0.54^{+}$ & 0.39 & $0.69^{+}$ & -0.16 & $0.56^{+}$ & $-0.53^{+}$ & $0.76^{+}$ \\
\hline
\end{tabular}

${ }^{+}$highly significant correlation $\left(P<10^{-6}\right)$

MUFA - monounsaturated fatty acids; C 18:1 - oleic acid; YDC - yield of dry capsules; YS - yield of seed; C 20:1 - gadoleic acid; C 18:0 - stearic acid; C 18:3 - alpha-linolenic; SFA - saturated fatty acids; C 16:0 palmitic acid; LC - oil content; C 18:2 - linoleic acid; PUFA - polyunsaturated fatty acids 
climatic conditions. Another separated cluster of samples represents high morphine variety Buddha, characterised by lower C 18:3 and oil content (LC) and higher $\mathrm{C}$ 16:0 contents compared to all other genotypes. Concerning this cluster individually, poppy samples from Malý Šariš are also separated from Vígl'aš-Pstruša. Hence, the PC 1 represents original variables OA/LA, MUFA, C 18:1, PUFA, and C 18:2, UI as well as oil content (LC), yield of seed and capsules (YDC and YS) with the highest loadings for this vector. In addition, the PC 2 represents the original descriptors $C$ 16:0, C 16:1, SFA and C 20:1 and contributes to the separation of samples in relation to their genotype. Also, samples denoted with number 2, which are mixed in group of locality 1 (Malý Šariš) belongs to special genotypes - the white- and ochre-seeded varieties characterised with higher levels of C 18:2 and LC, causing the aggravated stability in storage. On the other hand, white- and ochre-seeded varieties differed in terms of their lower levels of C 18:1, YDC and YS.

According to the result, it can be concluded the positive correlation of LC with C 18:2 (and therefore, also with PUFA and UI) and their negative correlation with $\mathrm{C}$ 18:1, calculated variables MUFA, $\mathrm{OA} / \mathrm{LA}$ and interestingly also, with YDC and YS. In other words, by increasing YDC and YS, the content of oil and linoleic acid level in seeds is decreasing, as it was shown also in correlation analysis.

\section{CONCLUSIONS}

Genotypes cultivated at locality Malý Šariš were characterised by higher oil content, concentrations of palmitic and linoleic acid. On the other hand, the situation was opposite at Vígl'aš-Pstruša. Genotypes cultivated at Víglaš-Pstruša contained the lower oil content, lower concentrations of palmitic and linoleic acid, but the higher amount of oleic acid. Genotypes with ochre and white colour of seed contained the highest oil content in both localities. However, white colour of seed was associated with higher AVs of oil, reflecting low anti-oxidative stability. Our results indicated that genotypes listed in the List of Registered Varieties of Slovak Republic were characterised by higher SV of oil. As major fatty acids were detected linoleic, palmitic and oleic acids. High-morphine genotype Buddha contained the highest levels of palmitic and oleic acid. Factors genotype, locality and their interactions were statistically significant $(P<0.05)$. High negative interrelation between linoleic and oleic acids levels was determined.

Acknowledgements: The work was supported by the projects APVV-0248-10 and VEGA 1/0233/12 from the Ministry of Education of the Slovak Republic.

\section{REFERENCES}

AOCS Official Methods. 1998. Acid value Cd 3d-63. In Official Methods and Recommended Practices of the American oil chemists society, fifth edition, AOCS Press, Champaign, IL (USA).

ASTM D464-05. 2010. Standard test methods for saponification number of naval store products including tall oil and other related products, ASTM International, West Conshohocken, PA, 2010.

ATINAFU, D.G. - BEDEMO, B. 2011. Estimation of total free fatty acid and cholesterol content in some commercial edible oils in Ethiopia, Bahir DAR. In Journal of Cereals and Oil seeds, vol. 2, no. 6, pp. 71-76. DOI: $10.5897 / \mathrm{JCO} 11.025$

AZCAN, N. - ÖZTURK, K.B. - KARA, M. 2004. Investigation of Turkish Poppy seeds and seed oils. In Chemistry of Natural Compounds, vol. 40, no. 4, pp. 370-372. DOI: $10.1023 / \mathrm{B}:$ CONC.0000048250.81843.0a

BAJPAI, S. - PRAJAPATI, S. - LUTHRA, R. - SHARMA, S. - KUMAR, A.N.S. 1999. Variation in the seed and oil yields and oil quality in the Indian germplasm of opium poppy Papaver somniferum. In Genetic Resources and Crop Evolution, vol. 46, no. 5, pp. 435439. DOI:10.1023/A:1008753604907

BEISSON, F. - LI, Y. - BONAVENTRURE, G. - POLLARD, M. - OHLROGGE, J.B. 2007. The acyltransferase GPAT5 is required for the synthesis of suberin in seed coat and root of Arabidopsis. In Plant Cell, vol. 19 , no. 1 , pp. 351-368. DOI: $10.1105 /$ tpc. 106 . 048033

BEREZIN, O.Y. - TUR'YAN, Y.A. - KUSELMAN, Y. SHENHAR, A. 1996. Rapid and complete extraction of free fatty acids from oilseeds for acid value determination. In Journal of the American Oil Chemists, Society, vol. 73, no. 12, pp 1707-1711. DOI: 10.1007/ BF 02517976

BOZAN, B. - TEMELLI, F. 2008. Chemical composition and oxidative stability of flax, safflower and poppy seed and seed oils. In Bioresource Technology, vol. 99, no. 14, pp. 6354-6359. DOI:10.1016/J. BIORTECH.2007.12.009

BROWSE, J. - WARWICK, N. - SOMERVILLE, C.R. - SLACK, C.R. 1986. Fluxes through the prokaryot- 
ic and the eukaryotic pathways of lipid synthesis in the 16:3 plant Arabidopsis thaliana. In Biochemistry Journal, vol. 235, no. 1, pp. 25-31. DOI: 10.1042/ bj 2350025

CANVIN, D.T. 1965. The effects of temperature on the oil content and fatty acid composition of the oils from several oil seed crops. In Canadian Journal of Bota$n y$, vol. 43, no. 1, pp. 63-69. DOI: 10.1139/b65-008

CODEX ALIMENTAIRUS COMMISSION, 1993. Graisses et huiles vegetables, division 11. Version Abregee FAO/WHO Codex Stan, 20-1981, 23-1981.

CONNOR, W.E. 2000. Importance of n-3 fatty acids in health and disease. In American Journal of Clinical Nutrition, vol. 71 , no. 1, pp.171S-175S.

ČERTÍK, M. - ŠAJBIDOR, J. 1996. Variability of fatty acid composition in strains Mucor and Rhizopus and its dependence on the submersed and surface growth. In Microbios, vol. 85, no. 344, pp. 151-160.

ČERTÍK, M. - JEŠKO, D. 2006. Genotype variability of fatty acids in cereals. In Oils, Fats and Lipids for a Healthier Future? : Proceedings of $4^{\text {th }}$ Euro Fed Lipid Congress. Madrid : Spain, October 1-4, 2006.

EKLUND, A. - AGREEN, G. 1975. Nutritive value of poppy seed protein. In Journal of the American Oil Chemists'Society, vol. 52, no. 6, p. 188-190. DOI: 10.1007/BF02672167

FAOSTAT DATABASE, 2014. In Mongabay. [online]. [cit. 20-11-2014] Dostupné na internete: <http:// data.mongabay.com/commodities/category/1-Production/1-Crops/296-poppy+seed/51-Production+Quantity $/ 5000$-World $+++\% 28$ Total $\% 29>$.

HEINE, R.J. - MULDER, C. - POPP-SNIJDERS, C. - van der MEER J. - van der VEEN, E.A. 1989. Linoleic acid-enrichment diet: long term effects on serum lipoprotein and apolipoprotein concentrations and insulin sensitivity in noninsulin - dependent diabetic patients. In American Journal of Clinical Nutrition, vol. 49 , no. 3 , pp. $448-456$.

HLINKOVÁ, A. - HAVRlentovÁ, M. - ŠUPOVÁ, J. - BEDNÁROVÁ, A. 2012. Poppy seed (Papaver somniferum L.): Effects of genotype and year of cultivation on variability in its lipid composition. In Journal of Microbiology, Biotechnology and Food Sciences, vol. 1 , pp. 908-922.

CHRISTOPERSON, S.W. - GLASS, R.L. 1969. Preparation of milk fat methyl esters by alcoholysis in an essentially nonalcoholic solution. In Journal of Dairy Science, vol. 52, no. 8, pp. 1289-1290. DOI: 10.3168 / jds.S0022-0302(69)86739-1

LUTHRA, R. - SINGH, N. 1989. Changes in fatty acid composition accompanying the deposition of triacylglycerols in developing seeds of opium poppy (Papaver somniferum L.). In Plant Science, vol. 60, no. 1, pp. 55-60. DOI: 10.1016/0168-9452(89)90043-5

MAKSYMIEC, W. 2007. Signaling responses in plants to heavy metal stress. In Acta Physiologiae Plantarum, vol. 29, no. 3, pp. 177-187. DOI:10.1007/S11738007-0036-3

MIKAMI, K. - MURATA, N. 2003. Membrane fluidity and the perception of environmental signals in cyanobacteria and plants. In Progress in lipid research, vol. 42, no. 6, pp. 527-543. DOI:10.1016/S01637827(03)00036-5

NERGIZ, C. - ÖTLES , S. 1994. The proximate composition and some minor constituents of poppy seeds. In Journal of the Science of Food and Agriculture, vol. 66, no. 2, pp. 117-120. DOI: 10.1002/jsfa.2740660202

ÖZCAN, M.M. - ATALAY, C. 2006. Determination of seed and oil properties of some poppy (Papaver somniferum L.) varieties. In Grasas y Aceites, vol. 57, no. 2, pp. 169-174. DOI: 10.3989/gya.2006.v57.i2.33

PERKINS, E.G. 1992. Effect of lipid oxidation on oil and food quality in deep frying. In ANGELO, A.J.ST. (Ed) Lipid Oxidation in Food, American Chemical Society, Washington, D.C., pp. 310-321.

RAHIMI, A. - KIRALAN, M. - ARSLAN, M. - BAYRAK, A. 2011. Variation in fatty acid composition of registered poppy (Papaver somniferum L.) seed in Turkey. In Akademik Gida, vol. 9, no. 3, pp. 22-25.

RAHIMI, A. - ARSLAN, N. - REZAEIEH, K.A.P. - GURBUZ, B. 2015. Variation in fatty acid composition of four turkish registered poppy (Papaver somniferum L.) seeds in two locations (Ankara and Boldavin) of Turkey. In European Online Journal of Natural and Social Sciences, vol. 4, no. 1, pp. 183-190.

SETHI, K.L. - SAPRA, L. - GUPTA, R. 2006. Performance of poppy cultivars in relation to seed, oil and latex yields under different environments. In Journal of the Science of Food and Agriculture, vol. 52, no. 3, pp. 309-313. DOI: $10.1002 /$ jsfa.2740520304

SLOVENSKÁ TECHNICKÁ NORMA (STN 46 1011-28), Skúšanie obilnín, strukovín a olejnín. Skúšanie olejnin. Stanovenie obsahu tuku (n-hexánového alebo petroéterového extraktu) [Testing cereals, legumes and oil-bearing crops. Testing oil-bearing crops. Fat content determination]. Praha: Vydavatelství Úřadu pro normalizaci a měrení, 1988, $4 \mathrm{p}$.

TAMZID, H.M. - ALAM, M.T. - ISLAM, M.A.U. 2007. Physico-chemical and nutritional studies of Terminalia belerica roxb. Seed oil and seed kernel. In Journal of Bio-Science, vol. 15, pp. 117-126. DOI: 10.3329/ jbs.v15i0.2211

ÚKSÚP, 2011. Listina registrovaných odrôd pre rok 2011. In Vestnik MPRV SR, vol. 43, čiastka 30.

VALIZADEH, N. - RAHIMI, A. - ARSLAN, N. 2014. Variation in fatty acid composition of three turkish slit flower opium poppy (Papaver somniferum L.) lines. In International Journal of Biosciences, vol. 4, no. 2, pp. 268-274. DOI: 10.12692/ijb/4.1.268-274

VAŠÁK, J. 2010. Mák. Praha: Powerprint, p. 336. ISBN 978-80-904011-8-1

WAGNER, K.H. - ISNARDY, B. - ELMADFA, I. 2003. Effects of seed damage on the oxidative stability of poppy seed oil. In European Journal of Lipid Science and Technology, vol. 105, no. 5, pp. 219-224. DOI: 10.1002/ej1t.200390044

Received: March 10, 2015 